\begin{tabular}{l|l}
\hline Notaice & e-ISSN: $2655-9404$ \\
Vol. 01 No. 1, Juni 2018 & DOI: $10.20473 /$ ntr.v1i1.9100 \\
\hline
\end{tabular}

Article history: Submitted 1 May 2018; Accepted 15 May 2018; Available online 1 June 2018.

\title{
Perlindungan Hukum Terhadap Penumpang Angkutan Umum: Studi Pada Taksi Blue Bird di Kota Denpasar
}

\author{
R. Ray Audi Stevan Bimaputra \\ Rayaudistevan21@yahoo.com \\ Universitas Airlangga
}

\begin{abstract}
This paper entitled "Legal Protection Against Public Transport Passenger: Study In Blue Bird Taxis in Denpasar". Transportation in the life of society has a very important role, because in the transport of almost all economic activities and community activities in general can run smoothly. Legal protection is a matter of protecting the subjects of law through legislation in force and forced to implement the sanction. Responsibility is the obligation to give answers that a calculation of all the things that happened and the obligation to provide recovery of damages that may be caused. The Method of writing this essay using juridical empirical, ie a method to conduct research directly to the field to get the truth accurately in writing of this, the law in konsepkan as a symptom empirical that can be observed in real life, in conducting direct research conducted case studies in the field and also did an interview how the protection of passengers when the accident occurred which resulted in the loss and liability of the freight company Blue Bird in the event of accidents to passengers.
\end{abstract}

Keywords: Legal Protection; Responsibility; Passenger

\begin{abstract}
Abstrak
Penelitian ini berjudul "Perlindungan Hukum Terhadap Penumpang Angkutan Umum, Studi Pada Taksi Blue Bird Di Kota Denpasar". Pengangkutan dalam kehidupan masyarakat mempunyai peran yang sangat penting karena pengangkutan membantu kegiatan ekonomi dan kegiatan masyarakat. Perlindungan hukum merupakan suatu hal yang melindungi subyek-subyek hukum melalui peraturan perundang-undangan yang berlaku dan dipaksakan pelaksanaannya dengan suatu sanksi. Tanggung Jawab adalah kewajiban memberikan jawaban yang merupakan perhitungan atas semua hal yang terjadi dan kewajiban untuk memberikan pemulihan atas kerugian yang mungkin ditimbulkannya. Metode penulisan yang digunakan dalam penulisan ini menggunakan metode yuridis empiris, yaitu dengan suatu metode dengan melakukan penelitian secara langsung ke lapangan guna mendapatkan kebenaran yang akurat di dalam penulisan ini, hukum di konseptualisasikan sebagai suatu gejala empiris yang dapat diamati di dalam kehidupan nyata, dalam melakukan penelitian langsung melakukan studi kasus di lapangan dan juga melakukan wawancara bagaimana perlindungan terhadap penumpang apabila tejadi kecelakaan yang mengakibatkan kerugian dan tanggung jawab dari pihak perusahaan angkutan Blue Bird pada saat terjadi kecelakaan terhadap penumpang.
\end{abstract}

Kata Kunci: Perlindungan Hukum; Tanggung Jawab; Akibat Hukum.

\section{Pendahuluan}

Peran penting jasa transportasi ini dapat dilihat dengan semakin meningkatnya kebutuhan jasa angkutan bagi mobilitas orang serta barang dari dan ke seluruh pelosok tanah air. Menyadari begitu besarnya peran transportasi, maka transportasi perlu untuk ditata dalam suatu sistem transportasi nasional yang terpadu untuk 
mewujudkan tersedianya jasa transportasi yang aman, nyaman, cepat, teratur, dan dengan biaya yang dapat dijangkau oleh semua lapisan masyarakat.

Transportasi sebagai dasar untuk pembangunan ekonomi dan perkembangan masyarakat serta pertumbuhan industrialisasi. Dengan adanya transportasi menyebabkan adanya spesialisasi atau pembagian pekerjaan menurut keahlian sesuai dengan budaya, adat-istiadat, dan budaya suatu bangsa atau daerah. Pertumbuhan ekonomi suatu Negara atau bangsa tergantung pada tersedianya pengangkutan dalam Negara atau bangsa yang bersangkutan. ${ }^{1}$

Di Indonesia sendiri untuk angkutan umum yang tidak asing kita lihat ialah taksi, sekilas mendengar taksi pun kita akan langsung terpikirkan Blue Bird, karena memang perusahaan yang sudah berdiri pada tahun 1965 yang didirikan oleh Mutiara Fatimah Djokosoetono ini merupakan taksi yang pertama di Indonesia, sehingga setelah 5 tahun berjalan pada tahun 1970 akhirnya Blue Bird diresmikan oleh Gubernur DKI Jakarta, Ali Sadikin yang mengumumkan bahwa Jakarta akan memberlakukan izin resmi bagi operasional taksi tersebut, Blue Bird sendiri memiliki logo sederhana berupa siluet burung berwarna biru tua yang sedang melesat, hasil karya pematung Hartono. Ini berasal dari ide ibunya, tentang kisah 'The Bird of Happiness" yang sering ia baca saat masih kecil.

Sekitar tahun 1975, Purnomo Prawiro dipercaya untuk memimpin Blue Bird sebagai direktur operasional. Pada tahun 1985, Blue Bird dibawah kepemimpinannya sudah mencapai 2.000 unit taksi. Nilai-nilai dan brand yang ditanamkan adalah Blue Bird sebagai taksi ternyaman, teraman, dengan pengemudi yang santun. Pada 10 Juni 2000, ibunya wafat di RS Medistra, ia secara tidak langsung melanjutkan kepemimpinan ibunya di Blue Bird Group.

Dengan berlakunya UU No. 22 Tahun 2009 diharapkan dapat membantu mewujudkan kepastian hukum bagi pihak-pihak yang terkait dengan penyelenggaraan jasa angkutan, baik itu pengusaha angkutan, pekerja (sopir/ pengemudi) serta penumpang. Secara operasional kegiatan penyelenggaraan

\footnotetext{
${ }^{1}$ H.A.Abbas Salim, Manajemen Transportasi (PT Raja Grafindo 1993).[6].
} 
pengangkutan dilakukan oleh pengemudi atau sopir angkutan dimana pengemudi merupakan pihak yang mengikatkan diri untuk menjalankan kegiatan pengangkutan atas perintah pengusaha angkutan atau pengangkut. Pengemudi dalam menjalankan tugasnya mempunyai tanggung jawab untuk dapat melaksanakan kewajibannya yaitu mengangkut penumpang sampai pada tempat tujuan yang telah disepakati dengan selamat, artinya dalam proses pemindahan tersebut dari satu tempat ke tempat tujuan dapat berlangsung tanpa hambatan dan penumpang dalam keadaan sehat, tidak mengalami bahaya, luka, sakit maupun meninggal dunia. Sehingga tujuan pengangkutan dapat terlaksana dengan lancar dan sesuai dengan nilai guna masyarakat. ${ }^{2}$

Berdasarkan uraian tersebut di atas, maka permasalahan yang akan dikaji adalah sebagai berikut:

1. Perlindunganterhadappenumpangapabilatejadikecelakaanyang mengakibatkan kerugian?

2. Tanggung jawab dari pihak perusahaan angkutan (Blue Bird) pada saat terjadi kecelakaan terhadap penumpang?

\section{Pengertian Pengangkutan}

Menurut R. Djatmiko "Pengangkutan berasal dari kata angkut yang berarti membawa atau memindahkan sesuatu ketempat lain". ${ }^{3}$ Arti Pengangkutan dari Departemen Pendidikan dan Kebudayaan pun hampir sama yaitu usaha membawa, mengantar atau memindahkan orang atau barang dari suatu tempat ke tempat yang lain. ${ }^{4}$ Jadi, dalam pengertian pengangkutan itu dapat disimpulkan sebagai suatu proses kegiatan atau gerakan dari suatu tempat ke tempat lain. Di Negara kita pengangkutan dilakukan dengan bermacam-macam moda, yakni pengangkutan darat, baik melalui jalan raya maupun dengan kereta api, pengangkutan laut dan

\footnotetext{
${ }^{2}$ Soegijatna Tjakranegara, Hukum Pengangkutan Barang Dan Penumpang (Jakarta 1995).[21].

${ }^{3}$ R. Djatmiko D, Pengetahuan Hukum Dan Hukum Dagang (Angkasa 1996).[111].

${ }^{4}$ Departemen Pendidikan dan Kebudayaan, Kamus Besar Bahasa Indonesia (Balai Pustaka 1996).[45].
} 
pengangkutan udara. ${ }^{5}$

Pengangkutan dapat diartikan sebagai pemindahan barang dan manusia dari tempat asal ke tempat tujuan untuk memenuhi perikatan-perikatan yang lahir dari perjanjian-perjanjian tertentu. ${ }^{6}$ Dalam hal ini terkait unsur-unsur pengangkutan sebagai berikut: ${ }^{7}$

1. Ada sesuatu yang diangkut;

2. Tersedianya kendaraan sebagai alat angkutan;

3. Ada tempat yang dapat dilalui alat angkutan.

Pengangkutan dapat diartikan sebagai pemindahan barang dan manusia dari tempat asal ke tempat tujuan. ${ }^{8}$ Menurut pendapat R. Soekardono, pengangkutan pada pokoknya berisikan perpindahan tempat baik mengenai benda-benda maupun mengenai orang-orang, karena perpindahan itu mutlak perlu untuk mencapai dan meninggikan manfaat serta efisiensi.

\section{Pengertian Penumpang}

Dalam pasal 1 angka 25 Undang-Undang Nomor 22 Tahun 2009 tentang Lalu Lintas dan Angkutan Jalan Raya yang dimaksud penumpang adalah Penumpang adalah orang yang berada di Kendaraan selain Pengemudi dan awak Kendaraan. Dengan mengikatkan diri setelah membayar uang atau tiket angkutan umum sebagai kontraprestasi dalam perjanjian pengangkutan maka seseorang telah sah sebagai penumpang alat angkutan penumpang umum yang apabila mengalami kecelakaan diri, yang diakibatkan oleh penggunaan alat angkutan umum, selama penumpang yang bersangkutan berada dalam angkutan tersebut, yaitu saat naik dari tempat pemberangkatan sampai turun di tempat tujuan. Tiket penumpang adalah tanda bukti bahwa seseorang telaah membayar uang angkutan dan akibatnya berhak

\footnotetext{
${ }^{5}$ Ridwan Khairandy, Pengantar Hukum Dagang Indonesia (Gama Media atas kerja sama PSH FH UII 1999).[96].

${ }^{6}$ Hari Pramono Sution Usman Adji, Djoko Prakoso, Hukum Pengangkutan Di Indonesia (PT Rineka Cipta 1990).[5].

${ }^{7}$ Ridwan Khairandy (n 5).[195].

${ }^{8}$ ibid. [195].
} 
naik pesawat udara sebagai penumpang. Tiket penumpang juga menjadi tanda bukti telah ditutupnya perjanjian angkutan udara antara pengangkut dan penumpang. Jadi penumpang adalah salah satu pihak dalam perjanjian pengangkutan darat, sedangkan pihak lawannya adalah pengangkut darat. Tiket penumpang merupakan syarat dalam perjanjian pengangkutan darat, tetapi bukan merupakan syarat mutlak sebab tidak adanya tiket penumpang tidak berarti tidak adanya perjanjian pengangkutan.

\section{Perlindungan Terhadap Penumpang Apabila Terjadi Kecelakaan yang Mengakibatkan Kerugian}

Perlindungan Hukum Preventif, merupakan perlindungan yang diberikan oleh pemerintah yang bertujuan untuk mencegah sebelum terjadinya pelanggaran. Hal ini terdapat dalam peraturan perundang-undangan dengan maksud untuk mencegah suatu pelanggaran serta memberikan rambu-rambu atau batasan-batasan dalam melakukan suatu kewajiban.

Perlindungan Hukum Represif, merupakan perlindungan akhir berupa sanksi seperti denda, penjara dan hukuman tambahan yang diberikan apabila sudah terjadi sengketa atau telah dilakukan suatu pelanggaran dengan melalui intigasi (pengadilan) atapun non intigasi (masyarakat).

Di dalam perjanjian angkutan orang termasuk perjanjian angkutan umum ada dua subyek yang tersebut yaitu pihak pengangkut dan penumpang. Pengangkut sebagai salah satu subyek hukum dalam perjanjian tersebut memiliki hak dan kawajiban yang harus dipenuhi perikatan tersebut. Hak dan kewajiban pengangkut dapat dilihat dalam peraturan perundang-undangan dan beberapa pendapat sarjana. Perlindungan terhadap penumpang merupakan kewajiban utama bagi pengangkut itu sendiri, kewajiban pengangkut adalah mengangkut penumpang atau barang serta menerbitkan dokumen pengangkutan, sebagai imbalan haknya memperoleh biaya pengangkutan dari penumpang. ${ }^{9}$

Menurut Undang-undang Nomor 33 tahun 1964 tentang Dana Pertanggungan

${ }^{9}$ Abdulkadir Muhamad, Hukum Pengangkutan Darat, Laut, Udara (PT Cipta Bakti 1994).[176]. 
Wajib Kecelakaan Penumpang dan PP Nomor 17 tahun 1965 tentang Ketentuan Pelaksanaan Dana Pertanggungan Kecelakaan mengatur tentang kewajiban dari pengangkut itu.

1. Pengusaha angkutan wajib memungut iuran kepada penumpang dan menyetorkan hasilnya pada waktu yang telah ditentukan, apabila hak ini dilanggar akan dikenakan hukuman denda setinggi-tingginya Rp 1.000.000,- (satu juta rupiah) (Pasal 8 UU Nomor. 33/64);

2. Pemilik alat angkutan umum yang bersangkutan wajib memberikan pertanggungan jawab seluruh hasil pungutan iuran kepada penumpangnya (Pasal 3 ayat 2 Nomor 17/65).

Menurut Undang-Undang Nomor 22 tahun 2009 tentang Lalu Lintas dan Angkutan Jalan mengatur tentang kewajiban pengangkut. Kewajiban lain pengangkut adalah bertanggung jawab kepada pihak ketiga dalam perjanjian tersebut yaitu ahli waris dari pihak korban yang meninggal dunia, ganti rugi tersebut berdasarkan kedudukan kedua belah pihak, kekayaan dan keadaan, selain itu pengangkut juga bertanggung jawab terhadap perbuatan akibat-akibat kelelaian pegawainya sendiri dalam arti tidak siap untuk menghadapi ugas seperti: mengemudi karena terlalu lelah, mengantuk, dalam keadaan mabuk (human error) maka dalam hal ini pihak pengangkut akan menegosiasikan kepada pengemudinya mengenai bagaimana tanggung jawab tersebut untuk ditanggung bersama. Jadi pengangkut atau pemilik angkutan bertanggung jawab penuh terhadap proses pengangkutan yang dilakukan tersebut.

Hak dan Kewajiban penumpang diatur pada Keputusan Menteri Perhubungan Nomor KM 35/2003 pada pasal 84 1-5. Tertanggung dalam hal ini pembayar iuran wajib yang menjadi korban dari kecelakaan alat angkutan umum yang mengakibatkan korban menderita cacat atau meninggal dunia, berhak atas ganti rugi atau santunan dana dari pihak Jasa Raharja, sebaliknya mereka yang mempunyai kewajiban untuk. 1. Membayar iuran wajib dana pertanggungan wajib kecelakaan penumpang melalui perusahaan atau pengusaha alat angkutan penumpang.

2. Setiap penumpang wajib memberikan pembuktian pembayarn iuran wajib 
dengan penerimaan kupon iuran wajibnya tertera dalam karcis penumpag.

3. Pengusaha atau pemilik perusahaan alat angkutan penumpang, wajib memungut iuran wajib dari para penumpang dan memberikan kupon wajib dan menyetorkan hasilnya kepada PT. (Persero) Asuransi Kerugian Jasa Raharja. ${ }^{10}$

Didalam pertanggungan wajib kecelakaan penumpang dikenal dengan iuran wajib, maka tiap-tiap penumpang harus membayar iuran wajib bersamaan dengan uang pembelian tiket. Setiap tiket dikeluarkan harus disertai dengan kupon petanggungan sebagai surat bukti telah ditutupnya perjanjian petanggungan wajib kecelakaan penumpang antara pengusaha dan pembayar iuran. Ditinjau dari bagaimana alat bukti perjanjian pertanggungan yang diatur dalam Undang-Undang Nomor 33 Tahun 1964 Pasal 4. Akan tetapi didalam Undang-Undang Nomor 33 Tahun 1964 dan PP 17/1965 telah diletakkan suatu inti utama dari tujuan pemerintah bahwa: setiap penumpang harus membayar iuran wajib untuk mengikatkan dirinya didalam hubungan hukum pertanggungan.

Dalam prakteknya apabila terjadi lalai atau tidak memenuhi kewajibannya, untuk itu dalam hal perjanjian pertanggungan biasanya disertai dengan ancaman hukuman bila perjanjian tidak dilaksanakan. Perjanjian pada umumnya mengandung (3) tiga unsur sebagai berikut.

1. Memberi sekedar jaminan untuk melaksanakan perjanjian

2. Harus dinyatakan wanprestasi untuk berlakunya hukum

3. Yang diancam harus yang tertentu. ${ }^{11}$

Tujuan dari ancaman hukuman agar pihak tertanggung mau melaksanakan kewajibannya, yaitu melakukan prestasi pada penanggung sebagai isi dari perjanjian.

\section{Akibat Hukum dari Pengangkut/Pengusaha Taksi Blue Bird Apabila Terjadi Kecelakaan Terhadap Penumpang}

Seperti dikatakan di atas, bahwa dengan melakukan kewajibannya yakni membayar uang atau tiket kepada pengangkut maka dengan sendirinya penumpang

${ }^{10}$ Humas PT A.K. Jasa Raharja, Penjelasan Umum Dana Pertanggungan Wajib Kecelakaan Penumpang (1984).[17].

11 Wiryono Prodjodikoro, Asas-Asas Hukum Perjanjian (1974).[75]. 
tersebut dengan sendirinya telah mendapat perlindungan atas keselamatannya yang dijamin oleh hukum.

Bila seorang penumpang mengajukan tuntutan ganti rugi karena luka atau lainlainnya kepada pengangkut, cukuplah bila dia mendalilkan bahwa dia menderita luka disebabkan pengangkutan itu. ${ }^{12}$ Jika tuntutan itu dibantah oleh pengangkut, maka pengangkut harus membuktikan bahwa kelalaian atau kesalahan tidak ada padanya. Bila pembuktian pengangkut ini berhasil, maka giliran penumpang yang harus membuktikan adanya kelalaian atau kesalahan pada pengangkut.

Pasal 1602-w ayat 2 Kitab Undang-Undang Hukum Perdata berbunyi "Apabila majikan tidak memenuhi kewajibannya seperti tersebut dalam ayat 1 di atas, dan kelalaian mana mengakibatkan kerugian bagi si buruh, maka majikan wajib memberi ganti rugi. Syarat mutlak yang harus ada pada setiap tuntutan ganti rugi terhadap pengangkut ialah bahwa kerugian itu disebabkan oleh pengangkutan atau hal yang erat hubungannya dengan pengangkutan.

Mengenai besarnya jumlah ganti rugi, belaku azas-azas yang tercantum dalam Pasal 1246, 1247, dan 1248 Kitab Undang-Undang Hukum Perdata, yang pada pokoknya mengganti yang hilang dan laba yang tidak diperolehnya, dengan batasan bahwa kerugian itu layak dapat diperkirakan pada saat perjanjian pengangkutan itu dibuat dan lagi pula kerugian itu harus merupakan akibat langsung dari wanprestasi pengangkut. Bagi kerugian yang tidak dapat dinilai dengan uang, misalnya cacat badan, cacat pada mukanya dan lain-lain, bekas penumpang itu tetap berhak untuk menuntut ganti rugi kepada pihak Blue Bird. Sudah tentu kalau perselisihan tentang besarnya jumlah ganti rugi, hanya hakimlah yang berwenang menentukannya.

\section{Tanggung Jawab Dari Pihak Perusahaan Angkutan Blue Bird Pada Saat Terjadi Kecelakaan Terhadap Penumpang}

Bentuk pertanggung jawaban pelaku usaha terhadap konsumen yang meliputi:

1. Fault liability atau pertanggung jawaban karena kesalahan adalah seseorang

${ }^{12}$ H. M. N. Purwosutjipto, Pengantar Pokok Hukum Dagang Indonesia 3: Hukum Pengangkutan (Djambatan 2008).[52]. 
baru dapat dimintakan pertanggung jawabannya secara hukum jika ada unsur kesalahan yang dilakukannya. Dalam prinsip ini jelas bahwa setiap pengangkut harus bertanggung jawab serta mengganti rugi pihak yang dirugikan dan wajib membuktikan kesalahan pengangkut.

2. Presumption of liability priciple adalah tergugat selalu di anggap bertanggung jawab sampai dapat membuktikan tidak bersalah. Pengangkut selalu bertanggung jawab atas setiap kerugian yang timbul pada pengangkutan yang diselenggarakannya, tetapi pengangkut dapat membuktikan bahwa pengangkut tidk bersalah, maka pengangkut dibebaskan dari tanggung jawab membayar ganti rugi.

3. Strict liability atau tanggung jawab mutlak adalah pertanggung jawaban seluruhnya dari pelaku usaha atas kerugian yang dialami penumpang sepenuhnya akibat memanfaatkan atau menggunakan jasa yang diberikannya.

Dengan terjadinya perjanjian antara pengangkut dengan penumpang, disini telah terjadi hubungan hukum antara pengangkut dan penumpang. Hubungan yang diatur oleh hukum dinamakan hubungan hukum yang Akan menimbulkan hak dan kewajibannya antara para pihak.

Perusahaan Blue Bird mengoperasikan armada taksi yang memenuhi persyaratan layak jalan kendaraan bermotor, sebagaimana dimaksud dalam pasal 39 Peraturan Pemerintah Nomor 41 Tahun 1993. Pengusaha angkutan umum yang telah mendapatkan izin operasi wajib:

a. memenuhi ketentuan yang telah ditetapkan dalam izin operasi;

b. mengoperasikan kendaraan bermotor yang memenuhi persyaratan teknis dan laik jalan;

c. melaporkan apabila terjadi perubahan domisili perusahaan;

d. meminta pengesahan dari pejabat pemberi izin apabila terjadi perubahan penanggung jawab perusahaan;

e. melaporkan setiap bulan kegiatan operasional angkutan.

Selain itu pengusaha Blue Bird wajib untuk secara periodik melakukan uji coba berkala terhadap seluruh armada taksi yang dioperasikan, sesuai dengan ketentuan Pasal 13 Undang-Undang Nomor 14 Tahun 1992 juncto Pasal 148 Peraturan Pemerintah Republik Indonesia Nomor 44 Tahun 1993 Tentang Kendaraan dan pengemudi yang menyatakan bahwa setiap kendaraan bermotor berjenis mobil 
barang, kendaraan khusus dan kendaraan umumyang dioperasikan dijalan, wajib dilakukan uji berkala. Masa uji berkala selama 6 (enam) bulan. Untuk menjamin keselamatan penumpang taksi, pengusaha Blue Bird harus memperkerjakan seluruh pengemudi taksi maupun mekanik yang terampil, berpengalaman, memiliki kesadaran dan kedisiplinan dalam berlalu lintas serta memiliki dedikasi yag besar untuk melaksanakan kewajibannya dalam menjaga keselamatan penumpang dari tempat pemberangkatan sampai tiba ditempat tujuan.

Selain itu untuk menjamin keselamatan penumpang, perusahaan Blue Bird wajib mematuhi waktu kerja dan waktu istirahat pengemudi. Waktu kerja yang diatur yaitu maksimal 8 jam per hari, apabila dipaksakan untuk tetap mengemudi, besar kemungkinan pengemudi taksi tersebut telah mengalami titik lelah, sehingga dapat memperbesar resiko terjadinya kecelakaan. Halhal tersebut diatas adalah ketentuan-ketentuan yang harus dipatuhi, sebagai bentuk tanggung jawab perusahaan Blue Bird untuk menyelenggarakan pengangkutan dengan aman. Struktur organisasi yang digunakan pada perusahaan Blue Bird adalah struktur organisasi Garis dan fungsional, dimana pemilik usaha bertanggung jawab sepenuhnya kepada jalannya perusahaan.

\section{Tanggung jawab dari Perusahaan Angkutan Blue Bird pada saat terjadi kecelakaan terhadap Penumpang}

Apabila terjadi kecelakaan atas Taksi Blue Bird yang dinaiki penumpang, sehingga menimbulkan kerugian terhadap diri penumpang, maka perusahaan angkutan Taksi Blue Bird akan memberikan santunan asuransi kepada korban. Santunan asuransi tersebut diberikan melalui PT. Jasa Raharja. Dimana santunan tersebut berasal dari iuran wajib yang ditarik oleh perusahaan angkutan Taksi Blue Bird kepada penumpang yang dijadikan dalam biaya pengangkutan didalam argometer di dalam taksi. Menurut Suda Ardana, Kepala Bagian bahwa Taksi Blue Bird selama santunan asuransi tersebut belum keluar atau dalam proses maka perusahaan angkutan Taksi Blue Bird bersedia untuk menanggung terlebih dahulu. (wawancara tanggal 3 Juni 2016 kepada Bapak Suda Ardana, Kepala Bagian Blue Bird). 
Di dalam prakteknya, pengusaha angkutan bertanggung jawab apabila kecelakaan tersebut berasal dari pihak supir dikarenakan kesalahan atau kelalaian dalam mengemudikan taksinya. Jika dalam kecelakaan tersebut, apabila ada korban yang meninggal dunia ataupun mengalami luka-luka baik berat maupun ringan langsung dibawa ke rumah sakit terdekat. Bagi penumpang yang mengalami lukaluka, biaya perawatan rumah sakit sementara ditanggung sepenuhnya oleh perusahaan Taksi Blue Bird sampai penumpang sembuh. Jika biaya perawatan untuk sementara ditanggung oleh penumpang, maka penumpang dapat menuntut gantu rugi ke perusahaan angkutan Taksi Blue Bird dengan membawa seluruh kuitansi perawatan selama di rumah sakit. Selanjutnya pihak perusahaan minta ganti kerugian kepada PT. jasa Raharja dengan menyerahkan kuitansi tersebut sebagai tanda bukti pembayaran. (wawancara tanggal 3 Juni 2016 kepada Paskalis Parera Humas SPPBG Blue Bird).

\section{Kesimpulan}

Berdasarkan pembahasan di atas maka dapat disimpulkan sebagai berikut.

1. Perlindungan Hukum terhadap penumpang yang diberikan oleh Blue Bird yaitu memberi jaminan asuransi terhadap penumpang apabila mengalami kecelakaan.

2. Tanggung Jawab dari Blue Bird bersifat Fault liability atau pertanggung jawaban karena kesalahan adalah seseorang baru dapat dimintakan pertanggung jawabannya secara hukum jika ada unsur kesalahan yang dilakukannya. Dalam prinsip ini jelas bahwa setiap pengangkut harus bertanggung jawab serta mengganti rugi pihak yang dirugikan dan wajib membuktikan kesalahan pengangkut.

\section{Daftar Bacaan}

\section{Buku}

Abdulkadir Muhamad, Hukum Pengangkutan Darat, Laut, Udara (PT Cipta Bakti 1994).

H. M. N. Purwosutjipto, Pengantar Pokok Hukum Dagang Indonesia 3: Hukum Pengangkutan (Djambatan 2008).

H.A.Abbas Salim, Manajemen Transportasi (PT Raja Grafindo 1993). 
Humas PT A.K. Jasa Raharja, Penjelasan Umum Dana Pertanggungan Wajib Kecelakaan Penumpang (1984).

Kebudayaan DP dan, Kamus Besar Bahasa Indonesia (Balai Pustaka 1996).

R. Djatmiko D, Pengetahuan Hukum Dan Hukum Dagang (Angkasa 1996).

Ridwan Khairandy, Pengantar Hukum Dagang Indonesia (Gama Media atas kerja sama PSH FH UII 1999).

Soegijatna Tjakranegara, Hukum Pengangkutan Barang Dan Penumpang (Jakarta 1995).

Sution Usman Adji, Djoko Prakoso dan HP, Hukum Pengangkutan Di Indonesia (PT Rineka Cipta 1990).

Wiryono Prodjodikoro, Asas-Asas Hukum Perjanjian (1974).

\section{Peraturan Perundang-undangan}

Undang-Undang Tentang Dana Pertanggungan Wajib Kecelakaan Penumpang, Undang-Undang Nomor 33 Tahun 1964, Lembaran Negara Tahun 1964 Nomor 137, Tambahan Lembaran Negara Republik Indonesia Nomor 2720.

Undang-Undang Tentang Perlindungan Konsumen, Undang-Undang Nomor 18 Tahun 1999, Lembaran Negara Tahun 1999 Nomor 42, Tambahan Lembaran Negara Republik Indonesia Nomor 3821.

Undang-Undang Tentang Lalu Lintas dan Angkutan Jalan Raya, Undang-Undang Nomor 22 Tahun 2009, Lembaran Negara Tahun 2009 Nomor 96, Tambahan Lembaran Negara Republik Indonesia Nomor 5025.

Peraturan Pemerintah Nomor 17 Tahun 1965 Tentang Ketentuan Pelaksanaan Dana Pertanggungan Wajib Kecelakaan Penumpang.

Peraturan Pemerintah Nomor 41 Tahun 1993 Tentang Angkutan Jalan.

HOW TO CITE: R. Ray Audi Stevan Bimaputra, 'Perlindungan Hukum Terhadap Penumpang Angkutan Umum: Studi Pada Taksi Blue Bird Di Kota Denpasar' (2018) Vol. 1 No. 1 Notaire. 